\title{
Potensi Kadar Nira dan Produksi Beberapa Varietas Sorgum Manis (Sorghum vulgare) di Lahan Kering Area Hutan sebagai Bahan Baku Bioetanol
}

\author{
Praptiningsih Gamawati Adinurani ${ }^{1}$, Sri Rahayu ${ }^{2}$, Luluk Sulistiyo Budi ${ }^{3}$ \\ ${ }^{1}$ Dosen Fakultas Pertanian, Universitas Merdeka Madiun, Jl. Serayu No. 79, Madiun, 63133 \\ E-mail: praptiningsih@unmer-madiun.ac.id \\ ${ }^{2}$ Dosen Fakultas Pertanian, Universitas Merdeka Madiun, Jl. Serayu No. 79, Madiun, 63133 \\ E-mail: srirahayu@unmer-madiun.ac.id \\ ${ }^{3}$ Dosen Fakultas Pertanian, Universitas Merdeka Madiun, Jl. Serayu No. 79, Madiun, 63133 \\ E-mail: luluksb@unmer-madiun.ac.id
}

\begin{abstract}
Sweet sorghum is one of the bioethanol producing plants that can be cultivated on dry land with a wide climate range. The study aims to utilize dry land forest areas for the development of several varieties of sweet sorghum as a bioethanol feedstock. The types used are Suri 3, Kawali, Super 2 and Suri 4 varieties which cultivated at various biofertilizer doses per plant, namely 5 g, 10 g, and $15 \mathrm{~g}$. This experiments used Randomized Block Designed factorial followed by Duncan's Multiple Range Test. The results showed that the Suri 3, Kawali and Super 2 varieties had above-average agronomic and production characters with the highest values at stem height $(301.28 \mathrm{~cm})$, stem weight $(145.21 \mathrm{~g})$, and seed dry weight $(39.74 \mathrm{~g})$ achieved by the variety of Super 2 . Varieties of Suri 3 has the highest potential the content of sugar in the stem (16.69\%). Suri 4 variety produces the most volume of juice with the lowest of sugar content. The interaction of varieties and biofertilizer doses was significantly different against the number of nodules, and the highest of nodules number accomplished by Super 2 varieties at a dose of $10 \mathrm{~g}(11.77)$.
\end{abstract}

Keywords — : bioethanol feedstock; production character; development of varieties; biofertilizer.

\section{PENDAHULUAN}

Secara umum sorgum dikenal sebagai tanaman pangan namun tanaman sorgum manis lebih terkenal sebagai pakan ternak (livestock fodder) atau bahan baku bioetanol. Sorgum manis merupakan salah satu alternatif yang dapat digunakan untuk mengatasi kebutuhan Bahan Bakar Minyak (BBM) jenis premium yang semakin membengkak. Data Badan Pengatur Hilir Minyak dan Gas (BPH Migas) menunjukkan rata-rata konsumsi Premium mulai 18 Desember 2018 hingga 8 Januari 2019 , mencapai 33.990 Kiloliter (KL) dengan nilai tertinggi 40.3 ribu KL dan terendah 21.7 ribu KL. Capaian itu meningkat sekitar $8 \%$ dari konsumsi pada hari normal sekitar 31.267 KL (Amelia, 2019).

Faktor paling dominan yang mendorong kenaikan konsumsi BBM bersubsidi adalah penambahan jumlah kendaraan bermotor. Peningkatan konsumsi BBM berdampak pada semakin berkurangnya jumlah cadangan BBM, sehingga peluang pemanfaatan sumber bioenergi semakin besar. Bioenergi berasal dari tanaman salah satunya adalah sorgum manis, diharapkan dapat menanggulangi krisis energi di masa depan yang diperkirakan kebutuhan akan bahan bakar semakin meningkat.

Beberapa negara telah mengembangkan sorgum manis sebagai tanaman energi yang menghasilkan bioetanol. Dalam beberapa tahun terakhir, ada peningkatan minat dalam penggunaan sorgum manis untuk produksi etanol di India, Filipina, Cina dan Amerika Serikat (Godoy, 2011). Produksi bioetanol dari tanaman sorgum di Amerika Serikat dapat mencapai $10.000 \mathrm{~L}^{-1}$ dalam satumusim, India (3.000 - 4.000) $\mathrm{L} \mathrm{ha}^{-1}$ dan di China $7000 \mathrm{~L} \mathrm{ha}^{-1}$ (Talanca, 2011). Di India, bioetanol dari sorgum dapat digunakan sebagai bahan bakar untuk lampu penerangan (pressurized ethanol lantern) yang disebut Noorie dapat menghasilkan $(1.250$ - 1.300) lumens (kira-kira setara dengan bola lampu $100 \mathrm{~W}$ ), untuk kompor pemasak (pressurized ethanol stove) yang menghasilkan kapasitas panas $3 \mathrm{~kW}$. Selain itu, pemerintah India telah mengeluarkan kebijakan mencampur bioetanol sorgum dengan bensin untuk bahan bakar kendaraan bermotor (Rajvanshi and Nimbkar, 2005). Asumsi produktivitas sorgum dalam menghasilkan bioetanol di Indonesia sebesar (2000-3500) $\mathrm{L} \mathrm{ha}^{-1}$ per musim tanam sehingga dapat diperkirakan kebutuhan lahan untuk menghasilkan bioethanol per tahunnya (Talanca, 2011). Pada tahun 2018, pemerintah Indonesia berencana kembali mendorong penggunaan Bahan Bakar Nabati (BBN) jenis etanol (bioethanol) sebesar $2 \%$ (E2) sebagai campuran BBM.. Oleh karena itu kebutuhan bahan baku bioetanol meningkat. Jika konsumsi premium disubsitusi dengan dua persen bioetanol, maka akan dibutuhkan sekitar 420 ribu kiloliter bioethanol (Kardono, 2008).

Produksi bioetanol sangat ditentukan oleh kualitas tanaman sorgum manis yaitu kadar nira dalam batang atau kandungan karbohidrat dalam biji. Kadar nira dalam batang mempunyai rentang nilai yang lebar tergantung pada varietas tanaman sorgum manis. Hasil penelitian Shiringani dan Friedt (2009) memperoleh kadar nira batang sorgum manis antara (5.67 - 22.67) \%, sedangkan Vermerris et al. (2007) menyatakan bahwa total gula dalam nira antara $(9-20) \%$. Demikian pula pada galur harapan sorgum manis MB-3, MB-5, dan MM-4 mempunyai kadar nira masing-masing 15.2 \%, 14.6\% dan 15.5\% (Gati, 2018). 
Website : http://agritek.unmermadiun.ac.id/index.php/agritek

Di Indonesia, upaya pengembangan tanaman sorgum perlu dukungan ketersediaan teknologi, khususnya benih varietas unggul baru dengan potensi hasil tinggi. Balai Penelitian Tanaman Serealia, merupakan salah satu Unit Pelaksana Teknis (UPT) Badan Litbang Pertanian telah merilis varietas sorgum Numbu dan Kawali dengan potensi hasil $4-5$ t ha ${ }^{-1}$ di tahun 2001 (Subagyo dan Suryawati, 2013) juga varietas Super 1 dan Super 2 di tahun 2013 dengan potensi kadar nira antara $13.6 \%-$ $18.4 \%$ (Pabendon et al 2017). Peluang sorgum manis untuk dikembangkan di Indonesia pada lahan kering cukup luas. Areal yang berpotensi untuk pengembangannya meliputi wilayah beriklim basah maupun wilayah beriklim kering atau wilayah yang musim hujannya pendek dan pada tanah yang kurang subur (Talanca, 2011).

Sorgum dapat dibudidayakan sebagai tanaman sisipan atau tumpang sari dengan padi gogo, kedelai, kacang tanah atau jagung baik di lahan tegal ataupun sawah tadah hujan. Penelitian ini bertujuan untuk mengetahui potensi kandungan nira dan produksi beberapa varietas tanaman sorgum manis sebagai bahan baku bioetanol yang dikembangkan di Indonesia terutama dalam pemanfaatan lahan kering area hutan.

\section{METODE PENELITIAN}

Percobaan di lapang dilakukan mulai bulan April 2017 - Juli 2017 di daerah kawasan Perhutani desa Kampung Baru Kecamatan Saradan Kabupaten Madiun dengan ketinggian $63 \mathrm{~m}$ dpl. Hasil analisa tanah lahan percobaan seperti pada Tabel 1. Tabel 1. Karakteristik Tanah Lahan Percobaan

\begin{tabular}{lc}
\hline Sifat & \\
\hline Tekstur & sandy loam \\
C org $(\%)$ & 1,59 \\
CEC $\left[\right.$ meq $\left(100 \mathrm{~g}^{-1}{ }^{-1}\right]$ & 82,32 \\
N total $(\%)$ & 1.15 \\
P total $(\mathrm{ppm})$ & 269,64 \\
Olsen- P tersedia $(\mathrm{ppm})$ & 86,75 \\
C/N ratio & 1,5 \\
\hline
\end{tabular}

Percobaan menggunakan Rancangan Acak Kelompok Faktorial. Faktor pertama adalah varietas sorgum (V) terdiri atas varietas Suri 3 (V1), Kawali (V2), Super 2 (V3), dan Suri 4 (V4). Faktor kedua dosis biofertilizer per tanaman yaitu 5g (D1), $10 \mathrm{~g}$ (D2), dan $15 \mathrm{~g}$ (D3). Biofertilizer yang diaplikasikan merupakan gabungan mikroba yang terdiri atas Trichoderma sp, Pseudomonas flourescens, Bacillus subtilis, dan mikoriza indigenous. Petak percobaan berukuran $3.50 \mathrm{~m} \times 1.50 \mathrm{~m}$ dengan jarak tanam $70 \mathrm{~cm} \times 20 \mathrm{~cm}$.

Data yang diperoleh dianalisis dengan analisis ragam Rancangan Acak Kelompok Faktorial. Untuk mengetahui perbedaan perlakuan dilakukan uji dengan Duncan Multiple Range Test pada tingkat kepercayaan 5\%.

\section{III.HASIL DAN PEMBAHASAN}

Potensi kadar nira, pertumbuhan dan produksi varietas sorgum pada aplikasi biofertilizer terlihat pada Tabel 2. Tabel 2. Hasil Analisa Statistik Semua Variabel Pengamatan Percobaan Sorgum

\begin{tabular}{lccc}
\hline \multicolumn{1}{c}{ Variabel } & Interaksi & $\begin{array}{c}\text { Faktor } \\
\text { Varietas }\end{array}$ & $\begin{array}{c}\text { Faktor } \\
\text { Dosis }\end{array}$ \\
\hline Tinggi Batang $(\mathrm{cm})$ & tn & $* *$ & tn \\
DiameterBatang $(\mathrm{cm})$ & tn & tn & tn \\
Jumlah Ruas & $*$ & $* *$ & tn \\
Kadar Nira $(\%)$ & tn & $* *$ & tn \\
Panjang Malai $(\mathrm{cm})$ & tn & tn & tn \\
Berat Batang $(\mathrm{g})$ & tn & $*$ & tn \\
Berat Biji Basah per Batang $(\mathrm{g})$ & tn & $*$ & tn \\
Berat Biji Kering per Batang $(\mathrm{g})$ & tn & $* *$ & tn \\
Volume Nira 5 Batang $\left(\mathrm{L}^{-1}\right)$ & tn & tn & tn \\
\hline \multicolumn{2}{c}{ Keterangan: tn $=$ tidak nyata, $^{-1} *=$ sangat nyata } & $*=$ nyata
\end{tabular}

Interaksi antara varietas sorgum dengan aplikasi beberapa dosis biofertilizer pada fase pertumbuhan hanya berpengaruh nyata pada jumlah ruas (Gambar 1). Faktor varietas sangat nyata pengaruhnya terhadap tinggi batang, jumlah ruas (Tabel 3) dan kadar nira, berat batang, berat biji kering per batang (Tabel 4). Aplikasi dosis biofertilizer berpengaruh tidak nyata terhadap semua variable pengamatan (Tabel 2). 
Website : http://agritek.unmermadiun.ac.id/index.php/agritek

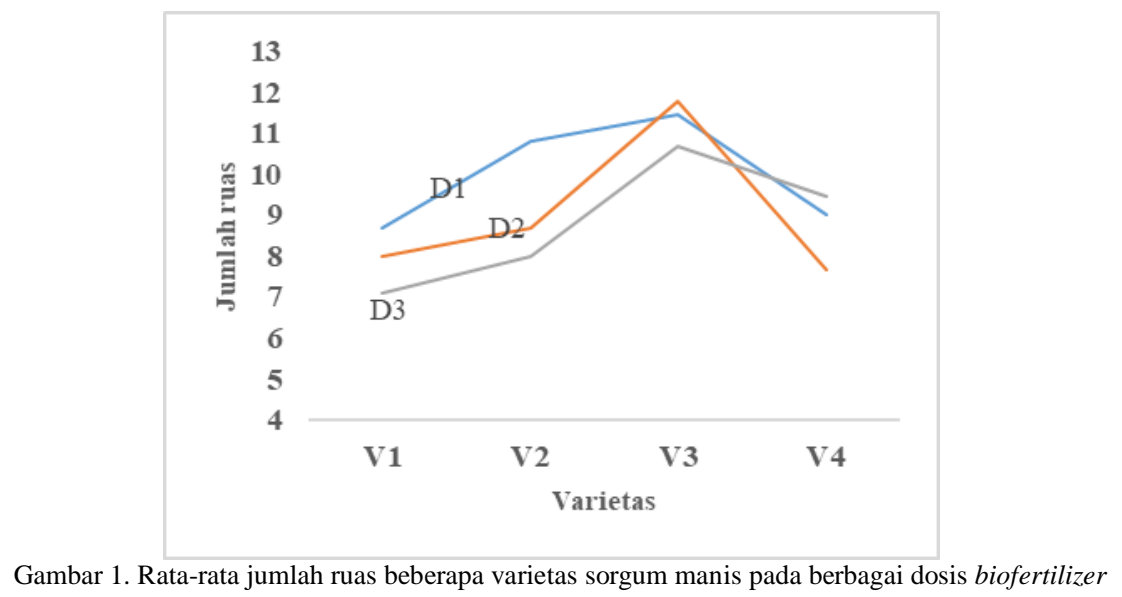

Pengaruh varietas Super 2 yang diberi $10 \mathrm{~g}$ biofertilizer (V3D2) menghasilkan jumlah ruas paling banyak (11.77) meskipun berdasarkan uji Duncan tidak berbeda nyata dengan yang diberi 5 g biofertilizer (V3D1) yaitu 11.44. Pada Gambar 1 tampak bahwa varietas Super 2 (V3) menghasilkan jumlah ruas terbanyak pada masing-masing dosis biofertilizer (D1, D2, D3) yang diaplikasikan dibanding varietas-varietas lainnya. Masing-masing varietas mempunyai respon berbeda pada berbagai dosis biofertilizer terhadap jumlah ruas tanaman sorgum. Varietas Suri 3 (V1) dan Kawali (V2) lebih respon pada dosis 5 g (D1). Sedangkan varietas Super 2 (V2) pada dosis $10 \mathrm{~g}$ (D2) dan varietas Suri 4 (V4) pada dosis $15 \mathrm{~g}$ (D3).

Biofertilizer yang diaplikasikan pada tanaman sorgum terdiri atas Trichoderma sp, Pseudomonas flourescens, Bacillus subtilis, dan mikoriza indigenous. Mikoriza dapat berinteraksi sinergis dengan rhizobakteri yang menguntungkan yaitu Bakteri Pelarut Fosfat (BPF) Pseudomonas flourescens (Laskhman dan Nadagouda, 2010). Pada tanah dengan kandungan P tersedia rendah (Tabel 1), mikoriza yang berasosiasi dengan BPF dapat menyerap unsur hara makro dan mikro terutama dalam memobilisasi unsur P. Mikoriza meningkatkan luas zona penyerapan unsur hara dan air oleh akar sehingga unsur hara menjadi tersedia bagi tanaman yang berdampak pada ketahanan tanaman terhadap cekaman air dan serangan hama penyakit (Prafithriasari dan Nurbaity, 2010). Mikoriza juga mampu meningkatkan aerasi tanah yang akan berdampak pada aktivitas kehidupan BPF. Bakteri Pelarut Fosfat merupakan bakteri yang membantu pelarutan fosfor di dalam tanah sehingga menjadi tersedia bagi tanaman. Bakteri ini akan aktif melarutkan unsur $\mathrm{P}$ terutama pada lahan dengan kadar $\mathrm{P}$ tersedia rendah. Penelitian Cruz dan Ishii (2012) menunjukkan bahwa mikoriza berinteraksi positif dengan BPF. Dijelaskan pula bahwa BPF yang berasosiasi dengan mikoriza memiliki waktu hidup yang lebih panjang (Jansa et al., 2013).

\begin{tabular}{cccc} 
Tabel 3. Respon Varietas Sorgum Manis terhadap Tinggi Batang dan Jum \\
\hline Varietas & $\begin{array}{c}\text { Tinggi batang } \\
\text { (cm) }\end{array}$ & $\begin{array}{c}\text { Jumlah } \\
\text { ruas }\end{array}$ & $\begin{array}{c}\text { Diameter } \\
\text { batang (cm) }\end{array}$ \\
\hline V1 & $268.03 \mathrm{~b}$ & $7.93 \mathrm{a}$ & $1.27 \mathrm{a}$ \\
V2 & $192.38 \mathrm{a}$ & $9.15 \mathrm{ab}$ & $1.44 \mathrm{a}$ \\
V3 & $301.28 \mathrm{~b}$ & $10.37 \mathrm{~b}$ & $1.39 \mathrm{a}$ \\
V4 & $181.29 \mathrm{a}$ & $9.63 \mathrm{ab}$ & $1.40 \mathrm{a}$ \\
\hline
\end{tabular}

Varietas Super 2 (V3) sangat respon terhadap tinggi batang dan menghasilkan batang tanaman tertinggi (301.28 cm) meskipun secara statistik tidak berbeda nyata dengan tinggi batang $268.03 \mathrm{~cm}$ dari varietas Suri 3 (V1). Adapun diameter batang ke empat varietas sorgum manis berbeda tidak nyata.

Berdasarkan data tinggi batang dan jumlah ruas pada Tabel 3, justru varietas Suri 3 (V1) mempunyai rata-rata ruas batang paling panjang dibanding ke tiga varietas lainnya. Namun demikian jumlah ruas terbanyak tetap dimiliki oleh varietas Super 2 (V3). Ruas batang sorgum manis berpengaruh terhadap tingkat kemanisan. Putrianti (2013) menyatakan bahwa kadar nira (brix) untuk ruas bagian bawah $14.85 \%$, bagian tengah $13.08 \%$ dan ruas bagian atas $11.53 \%$. Hasil ini menunjukkan bahwa semakin ke atas dari bagian batang sorgum manis semakin menurun kadar niranya. Hal ini sejalan dengan kandungan nira pada batang tebu bahwa bagian batang tebu yang paling manis di mulai dari bagian terbawah yang berada dekat akar dan semakin mendekati pucuk semakin berkurang (Cakti,2013).

Tabel 4. Rata-rata kadar nira, berat batang, berat biji kering per batang dan volume nira beberapa varietas sorgum manis

\begin{tabular}{ccccc}
\hline Varietas & $\begin{array}{c}\text { Kadar } \\
\text { nira } \\
(\%)\end{array}$ & $\begin{array}{c}\text { Berat per } \\
\text { batang }(\mathbf{g})\end{array}$ & $\begin{array}{c}\text { Berat biji } \\
\text { kering per } \\
\text { batang }(\mathbf{g})\end{array}$ & $\begin{array}{c}\text { Volume nira } \\
\text { per 5 batang } \\
(\mathbf{m L})\end{array}$ \\
\hline $\mathrm{V} 1$ & $16.93 \mathrm{~b}$ & $110.14 \mathrm{ab}$ & $33.40 \mathrm{bc}$ & $37.89 \mathrm{a}$ \\
V2 & $14.38 \mathrm{~b}$ & $119.85 \mathrm{ab}$ & $28.16 \mathrm{ab}$ & $33.56 \mathrm{a}$ \\
V3 & $14.44 \mathrm{~b}$ & $145.21 \mathrm{~b}$ & $39.74 \mathrm{c}$ & $24.78 \mathrm{a}$ \\
V4 & $10.39 \mathrm{a}$ & $85.06 \mathrm{a}$ & $24.90 \mathrm{a}$ & $48.00 \mathrm{a}$ \\
\hline
\end{tabular}

Karakter penting yang dapat memberikan gambaran potensi suatu varietas sorgum manis sebagai bahan baku bioetanol adalah kadar nira. Hasil penelitian ini menunjukan bahwa kadar nira varietas Suri 3, Kawali dan varietas Super 2 tidak berbeda 
Website : http://agritek.unmermadiun.ac.id/index.php/agritek

nyata, namun varietas Suri mempunyai kandungan nira terbanyak (16.93\%). Kisaran kadar nira ke empat varietas antara (10.39 - 16.93) \% sejalan dengan hasil penelitian Vermerris et al. (2007) dan Shiringani dan Friedt (2009). Meskipun varietas Suri 4 mempunyai kadar nira terendah $(10.39 \%)$, tetapi volume nira per 5 batangnya tertinggi $(48.00 \mathrm{~mL})$ yang berbeda tidak nyata dengan ke tiga varietas lainnya.

Tampak pada Tabel 4, bahwa kadar nira tidak berkorelasi dengan berat batang maupun volume nira. Hal ini disebabkan kadar nira dan volume nira ditentukan oleh varietas dan panen. Sukmadi (2010) menyatakan bahwa sorgum manis yang akan digunakan sebagai bahan baku bioetanol sebaiknya dipanen pada umur 90-105 HST (Hari Setelah Tanam) atau terbaik pada umur panen 80 hari untuk varietas Numbu (Suparti dkk., 2012). Hasil penelitian-penelitian sebelumnya menunjukkan bahwa masing-masing varietas sorgum manis mempunyai karakter pertumbuhan dan produksi yang berbeda seperti yang terlihat pada Tabel 4. Varietas Suri 4 yang mempunyai kadar nira dan berat batang rendah namun mempunyai volume nira paling tinggi. Demikian pula varietas Suri 3 dengan kadar nira tertinggi juga menghasilkan berat batang dan volume nira yang cukup baik.

Kadar gula pada batang sorgum akan meningkat seiring dengan bertambahnya umur tanaman sampai fase pematangan biji. Kadar gula dalam batang akan mencapai maksimal apabila tanaman sorgum telah mengalami fase masak fisiologis. Seperti penelitian Agnal et al. (1992, dikutip dalam Sriagtula 2016) yang menghasilkan kadar gula maksimal beberapa genotip sorgum manis pada saat tanaman memasuki fase masak fisiologis (120 HST). Pada fase berbunga, kandungan gula dalam batang masih rendah yaitu antara $8.3 \%-14.00 \%$ kemudian meningkat selama fase soft dough sekitar $12.8 \%-16.6 \%$ (Wortmann and Regassa, 2011). Hal ini dikarenakan pada fase pembungaan mulai ada translokasi fotosintat untuk pembentukan biji sehingga sebagian gula dalam batang sorgum digunakan sebagai energi untuk menunjang proses fisiologi tanaman.

Menurut Djanaguiraman et al. (2013), sorgum manis adalah tanaman yang mempunyai dua sink (batang dan biji) dengan sistim source dan sink yang unik. Batang sorgum manis merupakan sink yang menyimpan fotosintat dalam bentuk disakarida larut seperti sukrosa. Selama proses penuaan, karbon hasil asimilat digunakan untuk membentuk karbohidrat tidak larut (selulosa) dan sintesis sukrosa. Sukrosa disimpan dalam batang dan biji (bentuk pati). Kondisi inilah yang menyebabkan terjadinya kompetisi karbon untuk keperluan dua sink yaitu biji dan batang pada tanaman sorgum manis. Kandungan gula batang dan produksi biji merupakan indikator bagaimana asimilat dibagi antara dua sink yaitu batang dan biji (Subramanian 2013). Hal tersebut ditunjukkan pada hasil penelitian dengan berat biji kering tertinggi (39.74 g) pada varietas Super 2 (V3) yang mempunyai kadar nira lebih rendah (14.44\%). Sebaliknya untuk varietas Suri 3 (V1) dengan kadar nira tertinggi $(16.93 \%)$ namun menghasilkan berat biji kering lebih rendah yaitu $33.40 \mathrm{~g}$.

\section{IV.KESIMPULAN}

Potensi kadar nira batang varietas Suri 3 (V1), Kawali (V2) dan varietas Super 2 (V3) yang dibudidayakan di lahan kering area hutan berbeda tidak nyata dengan kisaran antara $14.38 \%-16.93 \%$. Demikian pula karakter agronomi dan produksi (tinggi batang, berat batang, berat kering biji) ke tiga varietas tersebut diatas rata-rata sehingga dapat digunakan sebagai bahan baku etanol. Potensi kadar nira untuk varietas Suri 4 (V4) paling rendah yaitu $10.39 \%$ dengan volume nira paling tinggi. Respon ke empat varietas yang dicobakan secara bersama-sama pada ke tiga dosis biofertilizer terhadap jumlah ruas batang berbeda nyata dengan jumlah ruas terbanyak dicapai oleh varietas Super 2 pada dosis biofertilizer $10 \mathrm{~g}$.

\section{UCAPAN TERIMAKASIH}

Penulis mengucapkan terima kasih kepada Kementerian Riset, Teknologi, dan Pendidikan Tinggi Indonesia atas bantuan dana penelitian juga kepada Universitas Merdeka Madiun yang telah mendukung fasilitas penelitian.

\section{VI.DAFTAR PUSTAKA}

Amelia, A.R. (2019). Harga Lebih Murah, Konsumsi BBM Premium Naik Selama Natal dan Tahun Baru. 8/1/2019. https://katadata.co.id/berita/2019/01/08/harga-lebih-murah-konsumsi-bbm-premium-naik-selama-natal-tahun-baru. Diakses Pebruari 2019

Cakti. (2011). Pengolahan Gula Tebu: Mutu Tebu. http://cakti-pengolahangulatebu.blogspot.com/2011/. Diakses tanggal 7 Agustus 2014..

Cruz, A.F., and T. Ishii. (2012). Arbuscular Mycorrhizal Fungal Spores Host Bacteria that Affect Nutrient Biodynamics and Biocontrol of Soil Borne Plant Pathogens.Biols Open. 1(1): 52-57.

Edy, S. (2011). Aspek Budidaya, Prospek, Kendala, Dan Solusi Pengembangan Sorgum Di Indonesia. 21/4/2011. https://edysof.wordpress.com/2011/04/21/aspek-budidaya-prospek-kendala-dan-solusi-pengembangan-sorgum-di-indonesia/. Diakses Juni 2017.

Gati, E. (2018). Balitbangtan Siap Lepas Varietas Unggul Sorgum Manis Hasil Bioteknologi. Berita. BB Biogen. Badan Penelitian dan Pengembangan Pertanian. Kementerian Pertanian. 12/07/2018 http://biogen.litbang.pertanian.go.id/2018/07/balitbangtan-siap-lepas-varietas-unggul-sorgum-manishasil-bioteknologi/.. Diakses Januari 2019.

Godoy JGV. (2011). Sorghum Improvement as Biofuel Feedstock: Juice Yield, Sugar Content and Lignocellulosic Biomass. Kansas State University.

Jansa J., P. Bukovska, and M. Gryndler. (2013). Mycorrhizal Hyphae As Ecological Niche for Highly Specialized Hypersymbionts or just Soil Free Riders Front Plant Sci. 4: 134. http://ncbi.nlm.nih.gov/pmc/articles/PMC3655320/ (Diakses 24 Juni 2018)

Kardono. (2008). Potensi Pengembangan Biofuel Sebagai Bahan Bakar Alternatif. Prosiding Seminar Nasianal Teknik Pertanian 2008 - Yogyakarta, 18-19 November 2008. Hal. 1-22

Lakshman, H.C. and M.G. Nadagouda. (2010). Microbial Solubilization of P with The Use of AM Fungi on Nodulation and Yield on Vicia faba L. Int. J. Agri. Sci. 6(1): 319-321

Pabendon, M.B., R. Efendi, S.B. Santoso and B. Prastowo. (2017). Varieties of sweet sorghum Super-1 and Super-2 and its equipment for bioethanol in Indonesia. IOP Conf. Series: Earth and Environmental Science 65 : 1-10.

Prafithriasari, M dan A. Nurbaity. (2010). Infektivitas Inokulan Glomus sp. dan Gigaspora sp. pada Berbagai Komposisi Media Zeolit-Arang Sekam dan Pengaruhnya terhadap Pertumbuhan Sorgum (Sorghum bicolor). Jurnal Agrikultura 21(1): 39-45. 
Website : http://agritek.unmermadiun.ac.id/index.php/agritek

Putrianti, R.D. (2013). Pengaruh Lama Penyimpanan Batang Sorgum Manis (Sorghum bicolor (L.) Moench) terhadap Rendemen dan Brix Nira yang Dihasilkan. Skripsi. Universitas Hasannudin.

Rajvanshi, A.K. and Nimbkar, N. (2005). Sweet Sorghum R \& D at the Nimbkar Agricultural Research Institute (NARI). Maharashtra, India. www.nariphaltan.virtualave.net/sorghum.htm.

Shiringani, A. and W. Friedt. (2009). Genotype-environmental analysisof RIL population segregating for sugar-related traits in Sorghum bicolor L. Moench. Disertation. Faculty of Agricultural Sciences, Nutritional Sciences and Environmental Management. Justus-LiebigUniversityGiessen, Limpopo, Republic of South Africa, 103p.

Sriagtula, R. (2016). Evaluasi Produksi, Nilai Nutrisi Dan Karakteristik Serat Galur Sorgum Mutan Brown Midrib Sebagai Bahan Pakan Ruminansia. Thesis. Institut Pertanian Bogor.

Subagyo, H. dan Suryawati. (2013). Wilayah Penghasil dan Ragam Penggunaan Sorgum di Indonesia .Dalam Sumarno dkk. (Eds.). Sorgum Inovasi Teknologi dan Pengembangan. (hal.24-37). Badan Penelitian dan Pengembangan Pertanian. Kementerian Pertanian

Subramanian SK. (2013). Agronomical, Physiological and Biochemical Approaches to characterize Sweet Sorghum Genotypes for Biofuel Production. A Dissertation Doctor of Phylosophy, Departement Agronomy College of Agriculture Kansas State University, Manhattan. Kansas.

Sukmadi, B. (2010). Difusi pemanfaatan pupuk organik, pupuk hayati dan pestisida hayati pada budidaya sorgum manis (Sorghum bicolor L.) di Kabupaten Lampung Tengah. Jakarta, Indonesia: Balai Pengkajian Bioteknologi. Suparti, Asngad, A., dan Chalimah. (2012). Uji kualitas dan kuantitas produksi bioethanol batang tanaman sweet sorgum berbagai varietas skala laboratorium. Universitas Muhammadiyah Surakarta.

Talanca, A.H. (2011). Status Sorgum Sebagai Bahan Baku Bioetanol. Balai Penelitian Tanaman Serealia. Seminar Nasional Serealia. Hal. 556-560.

Vermerris, W., C. Rainbolt, D. Wright, and Y. Newman. (2007). Production of biofuel crops in Florida: sweet sorghum. Univ. Florida. http://edis.ifas.ufl. edu/AG298. (Diakses 17 Maret 2017). Wortmann CS, Regassa T. (2011). Sweet sorghum as a bioenergy crop for the US Great Plains, Intech Open Access Publisher Rijeka, Croatia 